\title{
Effect of dietary high-oleic acid and conventional sunflower seeds and their refined oils on fatty acid composition of adipose tissue and meat in broiler chickens* $^{*}$
}

\author{
L.T. Ortiz ${ }^{1,3}$, C. Alzueta ${ }^{1}$, A. Rebolé ${ }^{1}$, M.L. Rodríguez ${ }^{1}$, I. Arija ${ }^{1}$ \\ and $\mathrm{A}$. Brenes ${ }^{2}$ \\ ${ }^{1}$ Department of Animal Production, Veterinary Faculty, Complutense University \\ Ciudad Universitaria, 28040 Madrid, Spain \\ ${ }^{2}$ Department of Metabolism and Nutrition, Instituto del Frio, \\ Spanish National Research Council (CSIC) \\ 28040 Madrid, Spain
}

(Received 18 July 2005; revised version 7 November 2005; accepted 6 January 2006)

\begin{abstract}
The influence of different dietary fat source on performance, tissue fatty acid composition (abdominal fat, thigh and breast muscles) and abdominal fat melting point was evaluated in female broiler chickens. Birds were fed diets containing $80 \mathrm{~g} / \mathrm{kg}$ of added fat by the inclusion of high-oleic acid sunflower seed (HOASS) and conventional sunflower seed (CSS), their respective refined oils (HOASO and CSO) and lard during three weeks (from 21 to $42 \mathrm{~d}$ of age). Feed efficiency was significantly impaired by the inclusion of HOASS and CSS in diet when compared with HOASO, CSO and lard. The levels of the major fatty acids (palmitic, oleic and linoleic) in each animal tissue reflected the fatty acid profile of the dietary fat $\left(\mathrm{r}^{2}>0.83\right)$. The linear regression analysis between fatty acid content and melting point of abdominal fat gave the highest coefficient of determination for the saturated fatty acid content $\left(r^{2}=0.80\right)$. It is concluded that the seeds of high-oleic acid and conventional varieties of sunflower might be used in poultry feeding in order to increase, respectively, monounsaturated and polyunsaturated fatty acid contents in both abdominal adipose tissue and intramuscular fat. The feeding of both types of seeds had similar effects to their respective refined oils on the unsaturated to saturated fatty acid ratio of the chicken tissues and on the melting point of abdominal fat. Nevertheless, they showed a negative influence on fat firmness when compared with the dietary inclusion of lard.
\end{abstract}

KEY WORDS: broiler, high-oleic acid sunflower seed, sunflower seed, meat, adipose tissue, fatty acids

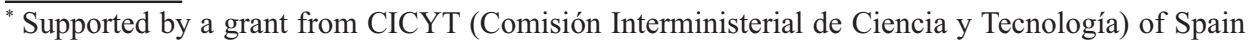
as a part of Project AGL2001-1116

${ }^{3}$ Corresponding author: e-mail: 1tortiz@vet.ucm.es
} 


\section{INTRODUCTION}

The nutritional benefits of unsaturated fatty acids (UFA) in human diets are well known. Numerous studies have shown that the substitution of dietary SFA for monounsaturated (MUFA) or polyunsaturated fatty acids (PUFA) reduces low density lipoprotein (LDL)-cholesterol concentrations in blood plasma (Mensik and Katan, 1989). There is also increasing evidence that MUFA decrease LDLcholesterol level without adversely affecting high density lipoprotein (HDL)cholesterol and reduces the susceptibility of LDL to oxidation, while some PUFA decrease both LDL- and HDL-cholesterol levels (Mattson and Grundy, 1985; Roche, 2001).

The manipulation of dietary fat with the purpose of altering the fatty acid composition of the chicken meat to tailor current health recommendations for humans has promoted the substitution of animal fat sources by some UFA-rich vegetable oils. An alternative and cheaper mean of achieving this aim could be to include whole oilseeds in the diets. Sunflower seed, one of the most widely cultivated oilseeds, contains about of $500 \mathrm{~g} / \mathrm{kg}$ very high UFA oil. Regarding the fatty acid composition, two main groups of sunflower varieties are commercially available: conventional (CSS), rich in linoleic acid, C18:2n-6 $(580 \mathrm{~g} / \mathrm{kg}$ total fatty acids TFA) (Ortiz et al., 1998) and high-oleic acid sunflower seed (HOASS), obtained recently, rich in oleic acid, C18:1n-9 (810 g/kg TFA) (Rodríguez et al., 2005).

However, broiler diets containing a relatively high concentration of C18:2n-6 have been negatively associated with soft fat tissues and high susceptibility of meat to oxidation (Zollitsh et al., 1997). The consistency and firmness of meat is related to the fat melting point, which is negatively correlated with the fatty acid unsaturation (Hrdinka et al., 1996; Sanz et al., 1999; Bavelaar and Beynen, 2003). On the other hand, diets with a relatively high content of MUFA have little effect on lipid oxidation when compared to diets with more saturated fatty acids (Lauridsen et al., 1997) and do not adversely affect to the quality of chicken meat (O’Neill et al., 1998).

Since the fatty acid composition of chicken meat can be considered an important determinant of its quality and due to the lack of data on the effect of HOASS and its refined oil (HOASO) on carcass fatty acid composition, the aim of the current study was: 1 . to examine the changes in the fatty acid composition of abdominal fat and intramuscular lipids by the incorporation of a rich MUFA source to broiler diets (HOASS and HOASO) instead of a PUFA (CSS and CSO) or a more saturated source (lard), and 2. to establish the relationship between the melting point and the fatty acid pattern of abdominal fat. 


\section{MATERIAL AND METHODS}

\section{Sunflower samples}

High-oleic acid sunflower seed (cv. Saxo) and conventional sunflower seed, commercially used for their oil extraction, were obtained from a commercial supplier (Koipesol Semillas SA, 41410 Carmona, Sevilla, Spain). The batches of sunflower seed were cleaned by hand to eliminate any foreign material, ground to pass through a $3.0 \mathrm{~mm}$ screen and stored at $-20^{\circ} \mathrm{C}$ until used. High-oleic acid and conventional sunflower refined oils (HOASO and CSO, respectively) and lard were provided by local suppliers. Fatty acid composition of the five fat sources is shown in Table 1.

Table 1 . Fatty acid composition of the dietary fat sources ${ }^{1}, \mathrm{~g} / \mathrm{kg}$ total fatty acids

\begin{tabular}{lccccc}
\hline & HOASS $^{2}$ & $\mathrm{HOASO}^{3}$ & $\mathrm{CSS}^{4}$ & $\mathrm{CSO}^{3}$ & Lard $^{3}$ \\
\hline C14:0 & ND $^{9}$ & $\mathrm{ND}$ & 1 & $\mathrm{ND}$ & 11 \\
$\mathrm{C} 16: 0$ & 44 & 43 & 59 & 65 & 224 \\
$\mathrm{C} 16: 1 \mathrm{n}-7$ & $\mathrm{ND}$ & $\mathrm{ND}$ & 1 & $\mathrm{ND}$ & 18 \\
$\mathrm{C} 18: 0$ & 51 & 43 & 64 & 36 & 125 \\
$\mathrm{C} 18: 1 \mathrm{n}-9$ & 807 & 730 & 284 & 330 & 438 \\
$\mathrm{C} 18: 2 \mathrm{n}-6$ & 72 & 163 & 581 & 556 & 145 \\
$\mathrm{C} 18: 3 \mathrm{n}-3$ & $\mathrm{ND}$ & $\mathrm{ND}$ & 1 & $\mathrm{ND}$ & 7 \\
C20:0 & 5 & 4 & 6 & 2 & 2 \\
C20:1 n-9 & $\mathrm{ND}$ & 3 & 3 & $\mathrm{ND}$ & 11 \\
C20:4 n-6 & $\mathrm{ND}$ & $\mathrm{ND}$ & $\mathrm{ND}$ & $\mathrm{ND}$ & 2 \\
MUFA $^{5}$ & 810 & 732 & 288 & 330 & 467 \\
PUFA $^{6}$ & 76 & 167 & 582 & 561 & 163 \\
SFA $^{7}$ & 114 & 101 & 130 & 109 & 370 \\
UFA $^{8} /$ SFA & 7.80 & 8.90 & 6.70 & 8.20 & 1.70 \\
\hline
\end{tabular}

1 fat source: HOASS $=$ high-oleic acid sunflower seed, HOASO $=$ high-oleic acid sunflower oil, $\mathrm{CSS}=$ conventional sunflower seed; $\mathrm{CSO}=$ conventional sunflower oil, and lard; ${ }^{2}$ Rodríguez et al. ( 2005); ${ }^{3}$ analysed in our laboratory; ${ }^{4}$ Ortiz et al. (1998); ${ }^{5}$ MUFA = monounsaturated fatty acids; ${ }^{6} \mathrm{PUFA}=$ polyunsaturated fatty acids; ${ }^{7} \mathrm{SFA}=$ saturated fatty acids; ${ }^{8} \mathrm{UFA}=$ unsaturated fatty acids; ${ }^{9} \mathrm{ND}=$ not detected

\section{Animals, diets and samples preparation}

Two hundred one-day-old female Cobb chickens, obtained from a commercial hatchery, were randomly housed in electrically heated starter battery brooders in an environmentally controlled room. The chickens were fed on a nutritionally adequate maize-soyabean meal diet for chickens of $3 \mathrm{wk}$ of age. At the end of third week, after having been deprived of feed overnight, 175 chickens were 
Table 2. Composition of experimental diets, $\mathrm{g} / \mathrm{kg}$ as fed

\begin{tabular}{|c|c|c|c|c|c|}
\hline \multirow{2}{*}{ Item } & \multicolumn{5}{|c|}{ Diet $^{1}$} \\
\hline & HOASS & HOASO & CSS & $\mathrm{CSO}$ & Lard \\
\hline \multicolumn{6}{|l|}{ Ingredients } \\
\hline maize & 561.0 & 532.3 & 573.6 & 532.3 & 532.8 \\
\hline soyabean meal & 159.6 & 349.1 & 139.7 & 349.1 & 348.6 \\
\hline high oleic sunflower seed & 180.0 & - & - & - & - \\
\hline high oleic sunflower oil & - & 80.0 & - & - & - \\
\hline conventional sunflower seed & - & - & 167.0 & - & - \\
\hline conventional sunflower oil & - & - & - & 80.0 & - \\
\hline lard & - & - & - & - & 80.0 \\
\hline soyabean protein isolate & 60.9 & - & 81.3 & - & - \\
\hline calcium carbonate & 9.0 & 9.0 & 9.0 & 9.0 & 9.0 \\
\hline dicalcium phosphate & 19.0 & 19.0 & 19.0 & 19.0 & 19.0 \\
\hline sodium chloride & 3.0 & 3.0 & 3.0 & 3.0 & 3.0 \\
\hline DL-methionine & 1.0 & 1.1 & 0.9 & 1.1 & 1.1 \\
\hline butylhidroxytoluol & 1.5 & 1.5 & 1.5 & 1.5 & 1.5 \\
\hline vitamin-mineral premix ${ }^{2}$ & 5.0 & 5.0 & 5.0 & 5.0 & 5.0 \\
\hline \multicolumn{6}{|l|}{ Analysed nutrient composition } \\
\hline crude protein & 197.0 & 192.0 & 197.1 & 208.5 & 205.8 \\
\hline $\begin{array}{l}\text { crude fat } \\
\text { fatty acids, } \mathrm{g} / \mathrm{kg} \text { total fatty acids }\end{array}$ & 106.4 & 105.5 & 111.3 & 106.1 & 109.8 \\
\hline $\mathrm{C} 16: 0$ & 70 & 76 & 92 & 85 & 195 \\
\hline $\mathrm{C} 16: 1 \mathrm{n}-7$ & 0 & 0 & 0 & 0 & 10 \\
\hline C18:0 & 38 & 32 & 25 & 33 & 86 \\
\hline C18:1 n-9 & 602 & 569 & 257 & 298 & 382 \\
\hline C18:2 n-6 & 254 & 289 & 607 & 562 & 283 \\
\hline $\mathrm{C} 18: 3 \mathrm{n}-3$ & 7 & 9 & 8 & 9 & 15 \\
\hline MUFA $^{3}$ & 602 & 569 & 257 & 298 & 392 \\
\hline PUFA $^{3}$ & 261 & 298 & 615 & 571 & 298 \\
\hline $\mathrm{SFA}^{3}$ & 122 & 120 & 126 & 128 & 295 \\
\hline $\mathrm{UFA}^{3} / \mathrm{SFA}$ & 7.20 & 7.33 & 6.94 & 6.81 & 2.39 \\
\hline AMEn, kcal /kg & 3200 & 3247 & 3200 & 3263 & 3256 \\
\hline
\end{tabular}

${ }^{1}$ fat source: HOASS $=$ high-oleic acid sunflower seed; HOASO $=$ high-oleic acid sunflower oil, CSS $=$ conventional sunflower seed, $\mathrm{CSO}=$ conventional sunflower oil, and lard; ${ }^{2}$ vitamin and mineral mixture supplying ( $\mathrm{mg} / \mathrm{kg}$ diet): 3 retinol, 55 cholecalciferol, $25 \mathrm{dl}$ - $\alpha$-tocopheryl acetate, 2.5 menadione, 3 thiamine, 6 riboflavin, 7 pyridoxine, 0.2 folic acid, 0.02 cyanocobalamin, 0.2 biotin, 25 calcium pantothenate, 50 niacin, 1300 choline chloride, $29.5 \mathrm{CuSO}_{4} 5 \mathrm{H}_{2} \mathrm{O}, 375.0 \mathrm{FeSO}_{4} \cdot 7 \mathrm{H}_{2} \mathrm{O}, 138.0 \mathrm{ZnSO}_{4}$ $\mathrm{H}_{2} \mathrm{O}, 277.0 \mathrm{MnSO}_{4} \cdot \mathrm{H}_{2} \mathrm{O}, 0.35 \mathrm{Na}_{2} \mathrm{SeO}_{3}, 0.20 \mathrm{KI}, 2.1 \mathrm{CoCl}_{2} \cdot 6 \mathrm{H}_{2} \mathrm{O}, 0.50 \mathrm{Na}_{2} \mathrm{MoO}_{4} \cdot 2 \mathrm{H}_{2} \mathrm{O} ;{ }^{3}$ as in Table 1

weighed, moved to grower-finisher batteries, and allocated into 35 pens; each pen contained 5 chickens and was assigned to one of the 7 replicates for each of the 5 dietary treatments during $21 \mathrm{~d}$ prior to slaughtering. Feed and water were provided ad libitum. The chickens were subjected to artificial fluorescent illumination for $23 \mathrm{~h} /$ day and handled according to the principles for the care of 
animals in experimentation established by Royal Decree 223/88 of Spain (1988). Experimental procedure was approved by the Animal Care and Use Committee of Complutense University (Madrid, Spain).

The chemical composition and the lipid profile of the experimental diets are shown in Table 2. Five isonitrogenous and isocaloric diets were formulated, included $80 \mathrm{~g} / \mathrm{kg}$ added fat corresponding to $180 \mathrm{~g} / \mathrm{kg}$ HOASS, $80 \mathrm{~g} / \mathrm{kg}$ HOASO, $167 \mathrm{~g} / \mathrm{kg}$ CSS, $80 \mathrm{~g} / \mathrm{kg}$ CSO and $80 \mathrm{~g} / \mathrm{kg}$ lard. Crude protein of diets was determined following the standard procedure of AOAC (1995). Metabolizable energy value (AMEn) of HOASS (Rodríguez et al., 2005) and CSS (Rodríguez et al., 1998) used to formulate the experimental diets were determined in our laboratory in preliminary experiments.

At $42 \mathrm{~d}$ of age, the chickens were weighed, wing-banded and fasted for $18 \mathrm{~h}$ before slaughtering. Broilers were stunned, slaughtered, bled and eviscerated in a commercial slaughterhouse. Carcasses were chilled, and abdominal fat, breast and thigh were removed by hand. For fatty acid analysis, 7 tissue samples per treatment, one per pen, were taken from breast excluding skin, thighs with skin and abdominal fat, freezed and stored at $-20^{\circ} \mathrm{C}$ until required. Abdominal fat samples for melting point determination (10 per treatment) were melted, filtered and placed into thin capillary glass tubes.

\section{Fatty acid profile and melting point determinations}

Crude fat of diets was determined by extraction in petroleum ether following acidification with $4 \mathrm{~N} \mathrm{HCl}$ (Wiseman et al., 1992). Total lipids from tissues were extracted following the procedure described by Folch et al. (1957). Fatty acid composition was determined by gas chromatography by comparison of their retention times with their corresponding standard (Sigma-Aldrich Química, SA, Alcobendas, Madrid, Spain). The lipid extracts were esterified with a mixture of boron trifluoride (in 10\% methanol), hexane and methanol (35:20:45, v/v/v) (Morrison and Smith, 1964). The resultant fatty acid methyl esters were analysed using a Chrompack CP 9001 Gas Chromatograph (Chrompack Instrumental BV, Middelbourg, The Netherlands) equipped with a WCOT fused silica capillary column (length, $30 \mathrm{~m}$; id, $0.32 \mathrm{~mm}$; film thickness, $0.5 \mu \mathrm{m}$ ), and a flame ionisation detector. Analyses were performed with a temperature programme from 170 to $250^{\circ} \mathrm{C}$ at a rate of $3.5^{\circ} \mathrm{C} / \mathrm{min}$. Both injector and detector were maintained at $250^{\circ} \mathrm{C}$. The carrier gas was nitrogen at a flow rate of 4.5 $\mathrm{mL} / \mathrm{min}$. MUFA, PUFA and SFA contents as well as UFA/SFA ratio were calculated.

The determination of melting point of the abdominal fat was carried out to estimate fat firmness. The melting point was measured by the AOAC method(1995). The capillary glass tube with the fat sample was placed into a water bath in front of a dark background and well lighted. The initial temperature of water bath was $5^{\circ} \mathrm{C}$ and the heating rate approximately $0.5^{\circ} \mathrm{C} / \mathrm{min}$. The melting point was defined 
as the temperature at which the sample fat becomes transparent (magnifying glass was used to detect complete melting). Average of three determinations per sample was used for statistical analysis.

\section{Statistical analysis}

Data of the different variables (performance parameters, fatty acid profile within each studied tissue and melting point of abdominal fat) were analysed statistically using one-way ANOVA and means with a significant $\mathrm{F}$ ratio were separated by the multiple range test of Duncan $(\mathrm{P}<0.05)$. Regression analysis was also applied to relate the fatty acid content of tissues $(y)$ to fatty acid content of diets $(x)$, as well as melting point of abdominal fat $(y)$ to fatty acid content of abdominal fat $(x)$. The statistical analyses were performed by using the Statgraphics software package (version 5.0, Statistical Graphics Corporation, Rockville, MD, USA).

\section{RESULTS}

The dietary fatty acid composition of the experimental diets (Table 2) reflected the fatty acid profile of the fat source. The predominant SFA was palmitic acid (C16:0) in the lard diet (195 $\mathrm{g} / \mathrm{kg}$ total fatty acids), the predominant MUFA was oleic acid (C18:1n-9) in the HOASS and HOASO diets $(602$ and $569 \mathrm{~g} / \mathrm{kg}$, respectively) and the linoleic acid (C18:2n-6) was the main fatty acid in the CSS and CSO diets (607 and $562 \mathrm{~g} / \mathrm{kg}$, respectively).

The values corresponding to the productive parameters are shown in Table 3.

Table 3. Effect of dietary fat source on performance parameters of chickens (21 to $42 \mathrm{~d}$ )

\begin{tabular}{lcccccc}
\hline & \multicolumn{5}{c}{ Diets $^{1}$} & \multirow{2}{*}{ SEM } \\
\cline { 2 - 6 } & HOASS & HOASO & CSS & CSO & Lard & \\
\hline Final body weight, g & 1761 & 1837 & 1767 & 1840 & 1826 & 41.5 \\
Weight gain, g day $^{-1}$ & $64.7^{\mathrm{b}}$ & $68.2^{\mathrm{a}}$ & $65.0^{\mathrm{b}}$ & $68.6^{\mathrm{a}}$ & $67.6^{\mathrm{ab}}$ & 0.99 \\
Feed intake, g day $^{-1}$ & 107.3 & 105.4 & 107.0 & 105.2 & 103.4 & 1.31 \\
${\text { Feed-to-gain ratio, } \text { g g }^{-1}}$ & $1.66^{\mathrm{a}}$ & $1.55^{\mathrm{b}}$ & $1.65^{\mathrm{a}}$ & $1.53^{\mathrm{b}}$ & $1.53^{\mathrm{b}}$ & 0.020 \\
\hline
\end{tabular}

${ }^{\mathrm{a}, \mathrm{b}}$ means in a row with no common superscripts are significantly different at $\mathrm{P} \leq 0.05$

${ }^{1}$ fat source: HOASS $=$ high-oleic acid sunflower seed; HOASO = high-oleic acid sunflower oil; $\mathrm{CSS}=$ conventional $\quad$ sunflower seed; $\mathrm{CSO}=$ conventional sunflower oil, and lard

The inclusion of $180 \mathrm{~g} / \mathrm{kg} \mathrm{HOASS}$ and $167 \mathrm{~g} / \mathrm{kg} \mathrm{CSS}$ in diets negatively affected the body weight gain of birds compared with their corresponding oil diets. The feed to gain ratio of birds consuming the diets containing seeds was significantly $(\mathrm{P}<0.05)$ higher than that of birds fed the diets containing oil or lard. 


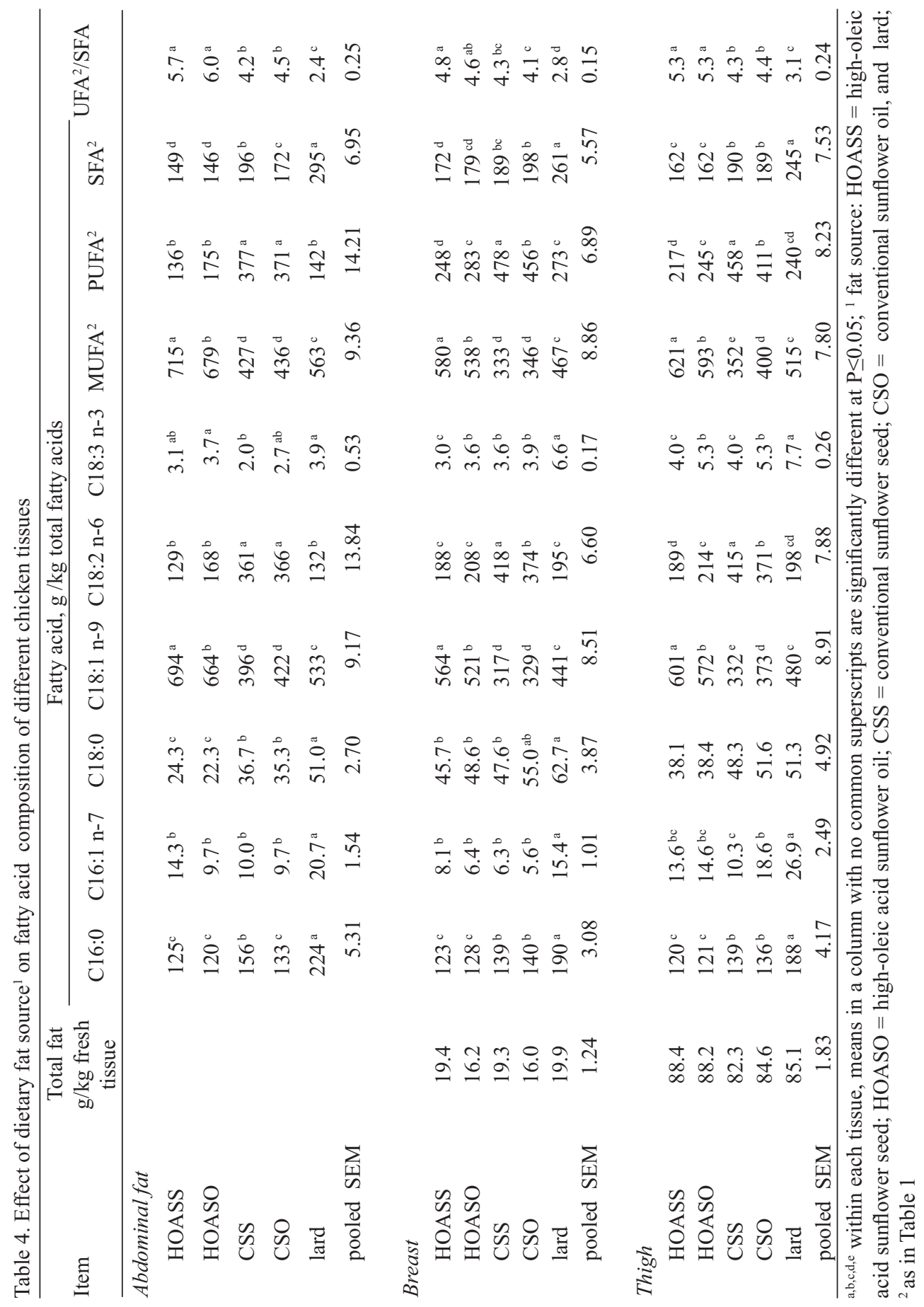


The effect of different dietary fat sources on the fatty acid composition of abdominal fat, breast and thigh is shown in Table 4, where it can be seen that there were significant $(\mathrm{P}<0.05)$ differences in the fatty acid content among dietary treatments in all tissues, with the exception of C18:0 in thigh. The contents of the major fatty acids (C16:0, C18:1n-9 and C18:2n-6) in each tissue reflected the fatty acid profile of the dietary fat: $\mathrm{C} 18: 1 \mathrm{n}-9$ was the predominant fatty acid in all tissues for HOASS, HOASO and lard diets, and C18:2n-6 was the main fatty acid in breast and thigh tissues for CSS and CSO diets. In general, no differences were found in $\mathrm{C} 16: 0$ and C18:0 (stearic acid) content in tissues when both varieties of sunflower seeds and their respective refined oils were compared (Table 4). A small increase in C18:1n-9 content (percentage of increase $4 \%$ in abdominal fat, $8 \%$ in breast and $5 \%$ in thigh) and, consequently, a reduction in C18:2n6 (13\% in thigh) and C18:3n-3 (linolenic acid) content (20 and 23\% in breast and thigh, respectively) have been observed with HOASS diet compared with HOASO diet. When CSS diet was compared with CSO diet, an increase in C18:2n- 6 content (percentage of increase $11 \%$ in breast and thigh) together with a reduction in C18:1n-9 and C18:3n-3 contents in thigh (12 and 33\%, respectively) were observed. UFA/SFA ratio did not significantly $(\mathrm{P}<0.05)$ vary in birds fed the diets containing seeds in comparison with those consuming the diets containing the corresponding refined oil.

As can be seen in Table 4, a differential response of abdominal and intramuscular fat to dietary fat source was found. In general, the differences among dietary treatments represented as relative differences in the contents of C16:0, C18:2n-6, PUFA, SFA and in the UFA/SFA ratio were more pronounced for abdominal fat than for breast and thigh. The greatest difference was found for C18:2n-6 in abdominal fat (180\% in CSS with respect to HOASS). Although lower than on abdominal fat, the results of the present study also showed a high effect of treatments on breast and thigh fat. The relationship between dietary and tissue fatty acid content in the different tissues was analysed by regression analysis (Table 5). Results obtained showed a close relationship for C16:0, C18:1n-9 and C18:2n-6 in the tissues studied ( $\mathrm{r}^{2}$ ranging from 0.97 for $\mathrm{C} 18: 2 \mathrm{n}-6$ in breast to 0.83 for $\mathrm{C} 16: 0$ in thigh) and consequently, the coefficients of determination for MUFA and PUFA were also very high (from 0.97 to 0.89 ).

The different fatty acid profile caused by the dietary fat sources resulted in significant $(\mathrm{P}<0.05)$ differences in the melting point of abdominal fat. The chickens fed the lard diet had the highest value $\left(36.0^{\circ} \mathrm{C}\right)$, whereas those fed the HOASS diet or its oil had the lowest values $\left(21.9\right.$ and $21.3^{\circ} \mathrm{C}$, respectively). The birds fed the CSS diet and its oil showed intermediate values $\left(24.4\right.$ and $25.9^{\circ} \mathrm{C}$, respectively). Differences between the diets containing the seeds and the diets containing their respective refined oils were not significant $(\mathrm{P}>0.05)$. To further 
asses this relationship, linear regressions relating melting point $(y)$ to fatty acid composition $(x)$ of abdominal fat were done. The results showed that the highest correlation was obtained for SFA content as independent variable $(\mathrm{r}=0.89$; $y=9.60+0.085 x) ;$ UFA/SFA ratio also gave a good estimation of the melting point $(\mathrm{r}=-0.83 ; \mathrm{y}=40.29-3.158 \mathrm{x})$.

Table 5. Linear regression analysis relating tissue fatty acids $(y)$ to dietary fatty acids (x)

\begin{tabular}{|c|c|c|c|c|c|c|c|}
\hline Item & $\mathrm{r}^{2}$ & $\mathrm{~A}$ & SE & $\mathrm{P}$ value & B & SE & P value \\
\hline \multicolumn{8}{|l|}{ Abdominal fat } \\
\hline C16:0 & 0.86 & 67.834 & 6.4672 & $* * *$ & 0.8086 & 0.05699 & $* * *$ \\
\hline C16:1 n-7 & 0.47 & 10.929 & 0.8094 & $* * *$ & 0.9786 & 0.18098 & $* * *$ \\
\hline C18:0 & 0.39 & 18.933 & 3.6202 & $* * *$ & 0.3500 & 0.07523 & $* * *$ \\
\hline C18:1 n-9 & 0.96 & 178.987 & 14.3551 & $* * *$ & 0.8611 & 0.03231 & $* * *$ \\
\hline C18:2 n-6 & 0.89 & -50.968 & 18.1268 & $* *$ & 0.7073 & 0.04243 & $* * *$ \\
\hline C18:3 n-3 & 0.07 & 1.714 & 0.8738 & ns & 0.1429 & 0.08738 & ns \\
\hline MUFA $^{1}$ & 0.95 & 205.85 & 15.4171 & $* * *$ & 0.8453 & 0.03456 & $* * *$ \\
\hline PUFA $^{1}$ & 0.89 & -53.613 & 18.6247 & $* *$ & 0.7194 & 0.04273 & $* * *$ \\
\hline SFA $^{1}$ & 0.83 & 70.940 & 10.3572 & $* * *$ & 0.7623 & 0.06008 & $* * *$ \\
\hline $\mathrm{UFA}^{1} / \mathrm{SFA}$ & 0.64 & 0.849 & 0.5110 & $\mathrm{~ns}$ & 0.6050 & 0.07964 & $* * *$ \\
\hline \multicolumn{8}{|l|}{ Breast } \\
\hline $\mathrm{C} 16: 0$ & 0.89 & 90.509 & 3.4652 & $* * *$ & 0.5158 & 0.03054 & $* * *$ \\
\hline C16:1 n-7 & 0.65 & 6.607 & 0.5079 & $* * *$ & 0.8821 & 0.11358 & $* * *$ \\
\hline C18:0 & 0.21 & 41.660 & 3.8307 & $* * *$ & 0.2396 & 0.07961 & $* *$ \\
\hline C18:1 n-9 & 0.92 & 141.615 & 15.5973 & $* * *$ & 0.6946 & 0.03511 & $* * *$ \\
\hline C18:2 n-6 & 0.97 & 19.428 & 8.4017 & $*$ & 0.6447 & 0.01967 & $* * *$ \\
\hline C18:3 n-3 & 0.89 & -0.175 & 0.2733 & ns & 0.4469 & 0.02733 & $* * *$ \\
\hline MUFA & 0.92 & 157.555 & 16.4025 & $* * *$ & 0.6971 & 0.03677 & $* * *$ \\
\hline PUFA & 0.97 & 82.294 & 8.7018 & $* * *$ & 0.6491 & 0.01996 & $* * *$ \\
\hline SFA & 0.79 & 128.509 & 6.8656 & $* * *$ & 0.4519 & 0.03983 & $* * *$ \\
\hline UFA/SFA & 0.72 & 1.957 & 0.2486 & $* * *$ & 0.3551 & 0.03874 & $* * *$ \\
\hline \multicolumn{8}{|l|}{ Thigh } \\
\hline C16:0 & 0.83 & 86.235 & 4.6852 & $* * *$ & 0.5267 & 0.04129 & $* * *$ \\
\hline C16:1 n-7 & 0.37 & 14.250 & 1.2927 & $* * *$ & 1.2607 & 0.28906 & $* * *$ \\
\hline C18:0 & 0.03 & 41.074 & 5.0568 & $* * *$ & 0.1044 & 0.10508 & ns \\
\hline C18:1 n-9 & 0.93 & 158.173 & 16.1666 & $* * *$ & 0.7434 & 0.03639 & $* * *$ \\
\hline C18:2 n-6 & 0.96 & 27.557 & 9.9081 & $* *$ & 0.6267 & 0.02319 & $* * *$ \\
\hline C18:3 n-3 & 0.80 & 0.574 & 0.4210 & ns & 0.4789 & 0.04210 & $* * *$ \\
\hline MUFA & 0.93 & 184.184 & 16.2097 & $* * *$ & 0.7360 & 0.03634 & $* * *$ \\
\hline PUFA & 0.96 & 46.799 & 10.5038 & $* * *$ & 0.6552 & 0.02410 & $* * *$ \\
\hline SFA & 0.63 & 124.067 & 9.4897 & $* * *$ & 0.4139 & 0.05505 & $* * *$ \\
\hline UFA/SFA & 0.53 & 2.108 & 0.4049 & $* * *$ & 0.3839 & 0.06311 & $* * *$ \\
\hline
\end{tabular}

${ }^{1}$ as in Table 1

$\mathrm{SE}=$ standard error

$* \mathrm{P}<0.05,{ }^{*} \mathrm{P}<0.01, * * * \mathrm{P}<0.001, \mathrm{~ns}=$ non significant 


\section{DISCUSSION}

The lower chicken performance observed for sunflower seed containing diets (HOASS and CSS) compared with those containing either refined oils (HOASO and CSO) or animal fat (lard) may be explained by the higher crude fibre content of the former diets. In fact, it has been reported than high fibre content may decrease the bulk density of diet and cause alterations in the jejunal mucosa (Arija et al., 2000). Likely, a decrease in the apparent digestibility of amino acids has been described by Rodríguez et al. (2005) when the concentration of fibre increased in the diet. Results of the present work are in accordance to those found by Arija et al. (1998) for CSS containing diets and those published by Rodríguez et al. (2005) in birds fed diets containing 100 and $200 \mathrm{~g} / \mathrm{kg}$ HOASS.

Changes in the composition of the abdominal and muscle fat caused by the variable composition of dietary fat confirm earlier findings (Leskanich et al., 1997a; O’Neill et al., 1998; López-Ferrer et al., 2001). The small differences found on fatty acid profile of tissues when sunflower seed diets (HOASS and $\mathrm{CSS}$ ) and their corresponding oil diets (HOASO and CSO) were compared, could be explained, at least in part, by the different concentration of individual fatty acids in seed diets with respect to oil diets.

By feeding chickens with a source of fat high in C18:1n-9 (HOASS or its oil) or C18:2n-6 (CSS or its oil) the proportion of MUFA and PUFA, respectively, increased in abdominal fat as well as in breast and thigh muscles. In the tissues studied, the proportion of MUFA surpassed $530 \mathrm{~g} / \mathrm{kg}$ of the total fatty acids (TFA) for chickens fed on HOAS (seed and oil) diets, and the concentration of PUFA exceeded $370 \mathrm{~g} / \mathrm{kg}$ of TFA for chickens fed on CS (seed and oil) diets. In breast and thigh muscles, this resulted in a two fold increase in MUFA/SFA ratio for HOASS and a two and a half increase in PUFA/SFA ratio for CSS in contrast to birds fed the lard diet. Similar increases in the MUFA content of fat tissue have been reported for chickens fed olive oil containing diets (O'Neill et al., 1998). Dietary HOAS (seed and oil) increased significantly the UFA/SFA ratio in all tissues in comparison to CS (seed and oil) diets (percentage of increase ranging from 36 to $10 \%$ ) and lard diet (percentage of increase from 150 to 64\%). The current study clearly revealed that muscle fatty acid can be manipulated to increase MUFA/SFA or PUFA/SFA ratios. In addition, future studies should concentrate on enrichment of poultry meat with n-3 PUFA since recommendations on human nutrition have stressed the importance of decreasing n-6/n-3 PUFA ratio (Leskanich, 1997b).

Results of the current work showed a more efficient modification of adipose than intramuscular fat profile, which was probably due to the physiological lipid storage function of adipose tissue. Several authors have reported this differential response, however, while Hrdinka et al. (1996) found a marked effect on abdominal 
fat and a limited effect on intramuscular lipids, Sanz et al. (2002) reported that the effect on intramuscular lipids depends on lipid class: triacylglycerols were highly affected whereas polar lipids were little affected by the diet. In broilers, lipid classes are unevenly distributed in different tissues. Ratnayake et al. (1989) reported that triacylglycerols accounted for 43,83 and $100 \%$ of total lipids in breast, thigh and skin of chickens fed a standard diet. Although lower than on abdominal fat, dietary effect on intramuscular fat was also high in the present study and, consequently, high correlation between dietary and abdominal fat as well as between dietary and intramuscular lipids was obtained for C16:0, C18:1n9 and $\mathrm{C} 18: 2 \mathrm{n} 6$. The slopes of the regression lines ranged from 0.69 to 0.86 for $\mathrm{C} 18: 1 \mathrm{n}-9$ and from 0.63 to 0.71 for $\mathrm{C} 18: 2 \mathrm{n}-6$, indicating an efficient incorporation of both fatty acids in tissues. These findings confirm the results reported by Scaife et al. (1994) for female broilers fed on diets containing $50 \mathrm{~g} / \mathrm{kg}$ of supplemental oil, that found a strong correlation between dietary and breast fatty acid contents. In contrast to this, the limited effect on muscle tissues found by Hrdinka et al. (1996) could be explained by the lower level of fat added (35 g/ $\mathrm{kg})$. As it has been stated, the dietary fatty acids incorporated into the muscular tissues will be relatively more diluted by de novo synthesized fatty acids at low fat intakes than at high fat intakes.

The inclusion of sunflower (seeds and oils) in chicken diets has resulted in significant decreases of melting point of abdominal fat with respect to lard diet. Of the regression analyses performed, linear equation relating melting point and SFA content of abdominal fat showed the highest coefficient of determination $\left(\mathrm{r}^{2}=0.80\right)$. Melting point is an indicator of the consistency of chicken fat (Bavelaar and Beynen, 2003), and it is associated to the fatty acid composition. Because decreasing the firmness of the fat tissue can be disadvantageous in the marketing of broiler meat (Valencia et al., 1993), it is important to consider this aspect of meat quality when shifting the fatty acid profile in chicken tissues. Recently, Bavelaar and Beynen (2003) demonstrated that fatty acid composition and melting point of the adipose tissue are strongly determined by the qualitative fatty acid intake, and the regression equations obtained can be used to formulate diets to modify broiler meat regarding to the health consumer and meat quality.

\section{CONCLUSIONS}

It is concluded that the seeds of high-oleic acid and conventional varieties of sunflower might be used in poultry feeding in order to increase, respectively, MUFA and PUFA contents in both abdominal adipose tissue and intramuscular fat. The feeding of both types of seeds had similar effects to their respective refined 
oils on the unsaturated to saturated fatty acid ratio of the chicken tissues and melting point of abdominal fat. Nevertheless, they showed a negative influence on fat firmness when compared with the dietary inclusion of lard.

\section{ACNOWLEDGEMENTS}

The authors are grateful to Koipe Semillas, S.A. (Carmona, Sevilla, Spain) for providing sunflower seeds used in this study. Also, authors wish to thank Avicu, S.A. (Guadalajara, Spain), and especially Ángel Yagüe, for slaughtering and processing birds.

\section{REFERENCES}

Arija I., Brenes A., Viveros A., Elices R., 1998. Effects of inclusion of full-fat sunflower kernels and hulls in diets for growing broiler chickens. Anim. Feed Sci. Tech. 70, 137-149

Arija I., Viveros A., Brenes A., Canales R., Pizarro M., Castaño M., 2000. Histological alterations in the intestinal epithelium caused by the inclusion of full-fat sunflower kernels in broiler chicken diets. Poultry Sci. 79, 1332-1334

AOAC, 1995. Official Methods of Analysis, Association of Official Analytical Chemists. 16th Edition. Arlington, VA

Bavelaar F.J., Beynen F.C., 2003. Relationships between dietary fatty acid composition and either melting point or fatty acid profile of adipose tissue in broilers. Meat Sci. 64, 133-140

Folch J., Lees M., Sloane-Stanly G.H.,1957. A simple method for isolation and purification of total lipids from animal tissues. J. Biol. Chem. 226, 497-509

Hrdinka C., Zollitsch W., Knaus W., Lettner F., 1996. Effects of dietary fatty acid pattern on melting point and composition of adipose tissue and intramuscular fat of broiler. Poultry Sci. 75, 208215

Lauridsen C., Buckley D.J., Morrissey P.A., 1997. Influence of dietary fat and vitamin E supplementation on $\alpha$-tocopherol levels and fatty acid profiles in chicken muscle membranal fractions and on the susceptibility to lipid peroxidation. Meat Sci. 46, 9-22

Leskanich C.O., Matthews K.R., Warkup C.C., Noble R.C., Hazzledine M., 1997a. The effect of dietary oil containing (n-3) fatty acids on the fatty acid, physicochemical, and organoleptic characteristics of pig meat and fat. J. Anim. Sci. 75, 673-683

Leskanich C.O., Noble R.C., 1997b. Manipulation of the $n-3$ polyunsaturated fatty acid composition of avian eggs and meat. World Poultry Sci. J. 53, 155-183

López-Ferrer S., Baucells M.D., Barroeta A.C., Galobart J., Grashorn M.A., 2001. n-3 Enrichment of chicken meat. 2. Use or precursors of long-chain polyunsaturated fatty acids: linseed oil. Poultry Sci. 80, 753-761

Mattson F.H., Grundy S.M., 1985. Comparison of effects of dietary saturated, monounsaturated and polyunsaturated fatty acids in plasma lipids and lipoproteins in man. J. Lipid Res. 26, 194-203

Mensink R.P., Katan M.B., 1989. Effect of a diet enriched with monounsaturated or polyunsaturated fatty acids on levels of low-density and high-density lipoprotein cholesterol in healthy women and men. N. Engl. J. Med. 321, 436-441 
Morrison W.R., Smith M.L., 1964. Preparations of fatty acid methyl esters and dimethylacetals from lipid with boron fluoride methanol. J. Lipid Res. 5, 600-608

O’Neill L.M., Galvin K., Morrissey P.A., Buckley D.J., 1998. Comparison of effects of dietary olive oil, tallow and vitamin $\mathrm{E}$ on the quality of broiler meat and meat products. Brit. Poultry Sci. 39, 365-371

Ortiz L.T., Rebolé A., Rodríguez M.L., Treviño J., Alzueta C., Isabel B., 1998. Effect of chicken age on the nutritive value of diets with graded additions of full-fat sunfower seed. Brit. Poultry Sci. 39, 530-535

Ratnayake W.M.N., Ackman R.G., Hulan H.W., 1989. Effect of redfish meal enriched diets on the taste and the n-3 PUFA of 42-day-old broiler chickens. J. Sci. Food Agr. 49, 59-74

Roche H.M., 2001. Olive oil, high-oleic sunflower oil and CHD. Brit. J. Nutr. 85, 3-4

Rodríguez M.L., Ortiz L.T., Alzueta C., Rebolé A., Treviño J., 2005. Nutritive value of high-oleic acid sunflower seed for broiler chickens. Poultry Sci. 84, 395-402

Rodríguez M.L., Ortiz L.T., Treviño J., Rebolé A., Alzueta C., Centeno C., 1998. Studies on the nutritive value of full-fat sunflower seed in broiler chick diets. Anim. Feed Sci. Tech. 71, 341-349

Róyal Decree 223/88 of Spain, 1988. Protection of animals used in experimental trials and other scientific purposes. Bol. Oficial del Estado 67, 8509-8511

Sanz M., Carmona J.M., López-Bote C.J., 2002. Quantitative effect of dietary fatty acids on fatty acid composition and fat firmness in broilers. Arch. Geflügelk. 66, 211-215

Sanz M., Flores A., Lopez-Bote C.J., 1999. Effect of fatty acid saturation in broiler diets on abdominal fat and breast muscle fatty acid composition and susceptibility to lipid oxidation. Poultry Sci. 78, 378-382

Scaife J.R., Moyo J., Galbraith H., Michie W., Campbell V., 1994. Effect of different dietary supplemental fats and oils on the tissue fatty acid composition and growth of female broiler. Brit. Poultry Sci. 35, 107-118

Valencia M.E., Watkins E.S., Waldroup A.L., Waldroup P.W., Fletcher D.L., 1993. Utilization of crude and refined palm and palm kernel oils in broiler diets. Poultry Sci. 72, 2200-2215

Wiseman J., Edmunds B.K., Shepperson N., 1992. The apparent metabolizable energy of sunflower oil and sunflower acid oil for broiler chickens. Anim. Feed Sci. Tech. 36, 41-51

Zollitsch W., Knaus W., Aichinger F., Lettner F., 1997. Effects of different dietary fat sources on performance and carcass characteristics of broilers. Anim. Feed Sci. Tech. 66, 63-73 